University at Buffalo School of Law

Digital Commons @ University at Buffalo School of Law

Journal Articles

Faculty Scholarship

Summer 2012

\title{
Vertical and Horizontal Perspectives on Rights Consciousness
}

David M. Engel

University at Buffalo School of Law

Follow this and additional works at: https://digitalcommons.law.buffalo.edu/journal_articles

Part of the Comparative and Foreign Law Commons

\section{Recommended Citation}

David M. Engel, Vertical and Horizontal Perspectives on Rights Consciousness, 19 Ind. J. Global Legal Stud. 423 (2012).

Available at: https://digitalcommons.law.buffalo.edu/journal_articles/477

Originally published in the Indiana Journal of Global Legal Studies. Reproduced with permission.

\section{IN COPYRIGHT}

This Article is brought to you for free and open access by the Faculty Scholarship at Digital Commons @ University at Buffalo School of Law. It has been accepted for inclusion in Journal Articles by an authorized administrator of Digital Commons @ University at Buffalo School of Law. For more information, please contact lawscholar@buffalo.edu. 


\title{
Vertical and Horizontal Perspectives on Rights Consciousness
}

\author{
DAVID M. ENGEL ${ }^{*}$
}

\begin{abstract}
It has become commonplace to assert that rights consciousness is expanding globally and that individuals worldwide are demonstrating an increasing awareness of and insistence upon their legal entitlements. To marshal empirical support for such claims is, however, exceedingly complex. One important line of socio-legal research on rights consciousness adopts what might be called a "vertical" perspective, tracing the flow of legal forms and practices from prestigious and authoritative centers of cultural production to local settings, where they may be adopted, resisted, or transformed. Vertical perspectives on global rights consciousness have broadened and enriched the field of law and society by examining linkages between local communities and world capitals, individuals and international organizations, and everyday interactions and systems of global regulation and enforcement. Yet, vertical perspectives in themselves cannot determine whether rights consciousness has expanded in relation to other systems of norm enforcement and dispute resolution. To answer this question, vertical perspectives must be combined with horizontal perspectives to ascertain what norms, practices, and beliefs prevail within various social fields where ordinary people engage in everyday interactions. A combination of vertical and horizontal perspectives is illustrated by research on rights consciousness in northern Thailand, which suggests the counterintuitive conclusion that rights consciousness may have diminished and that ordinary people rely instead on new forms of religiosity to justify inaction even in the face of serious legal harms.
\end{abstract}

* SUNY Distinguished Service Professor, University at Buffalo School of Law, State University of New York. Thanks to Frances Stephenson and Lauren Gray for assistance with the research, to Michael McCann for helpful comments, and to Jaruwan S. Engel for her many contributions and suggestions.

Indiana Journal of Global Legal Studies Vol. 19 \#2 (Summer 2012)

(C) Indiana University Maurer School of Law 


\section{INTRODUCTION}

Nearly one hour's drive from the city of Chiangmai in northern Thailand stands a small schoolhouse in a village surrounded by rice fields and longan orchards. Longan, known in Thai as lamyai, are a delectable fruit, similar to the lychee, and the villagers have found ready markets for their products throughout Thailand even during bad economic times. Despite the popularity of locally grown lamyai, youth in increasing numbers have left this village for the city, and many adults have sought wage labor far from the community in which they were born. Several years ago, as the student population dwindled, the school was closed and the children were sent to classes in a nearby town. Villagers still use the schoolhouse from time to time as a meeting center.

One December day several years ago, I traveled to this schoolhouse with a group of Thai graduate students to practice their interview skills in a class on rights consciousness. ${ }^{1}$ As the students dispersed with village volunteers in small interview groups seated on chairs and benches in the schoolyard, a poster on the wall of the old school building caught my eye. Entitled Rights of Children, it had apparently been sent to thousands of primary schools by Thailand's Ministry of Social Development and Human Security. The poster featured colorful cartoons of Thai children and adults, and beneath each cartoon a short statement summarized the rights that every child holds. These included the right to an education, the right to health, the right to receive information and ideas, the right to rest and leisure, the right to participate in cultural life and the arts, the right to remain with one's parents in accordance with the latter's wishes, the right to protection from sexual exploitation, and the right to free expression and the communication of information or views. Later, I realized that this impressive list of rights, translated into cartoons of everyday Thai life, came directly from the United Nations Convention on the Rights of the Child (CRC), which had been adopted by the U.N. General Assembly in 1989.2 The Thai government, after ratifying the CRC, attempted to

1. "Rights consciousness" refers to the understandings of law and the social practices through which individuals and groups come to embrace, ignore, manipulate, remain unaware of, or consciously reject rights in relation to their everyday experiences. See generally DAVID M. ENGEL \& FRANK W. MUNGER, RIGHTS OF INCLUSION: LAW AND IDENTITY IN THE Life STORIES OF AMERICANS WITH DiSABILITIEs (2003); PaTRICIA EWICK \& Susan S. SIlbey, The Common Place of LaW: STORIES From Everyday Life (1998); MICHAEL W. MCCANN, RIGHTS AT WORK: PAY EQUITY REFORM AND THE POLITICS OF LEGAL MoBiLizATION (1994).

2. U.N. Convention on the Rights of the Child, G.A. Res. 44/25, U.N. GAOR, 44th Sess., Supp. No. 49, U.N. Doc. A/44/49, at 167 (1989), reprinted in 28 I.L.M. 1448 (1989), 
translate its provisions into easily understandable words and images, which it then disseminated at the grassroots level by distributing the poster that I viewed in the village schoolhouse outside Chiangmai.

As I stood reading the poster, the Thai graduate students were busy asking their small groups of adults and teenagers about everyday activities and experiences that had potentially significant legal aspects, such as access to land and natural resources, disputing and dispute resolution, physical harms, and family conflicts. In these conversations, according to the later reports of the students, none of the villagers used the Thai term for rights, sit or sitthi. As far as the students could determine, the concept of rights had no part in the everyday discourse of the villagers. Although the interviewees had surely heard the word sit used by politicians, media figures, nongovernmental organization (NGO) representatives, or government officials, it was not part of their own everyday speech. Even when speaking of matters that could have important legal dimensions, they did not invoke the language of rights. Indeed, the findings of the students in this regard were consistent with my own research in Thailand over a period of many years.

The image of this tattered poster on the wall of a disused schoolhouse now strikes me as symbolic. Like many symbols, it can be read in different ways. On the one hand, the poster could be taken as evidence of the transnational expansion of the ideology of rights, from distant centers of neoliberal cultural production in Europe and North America through the ministries of the Thai government down to the village level. This reading is what might be called a vertical perspective on transnational legalism. Vertical research traces concepts or practices from what are conceived as higher, more powerful, prestigious, or inclusive levels of legal organization to what are conceived as lower, less powerful, and more localized levels. This type of research burrows

with corrections at 29 I.L.M. 1340 (1990) [hereinafter CRC]. The CRC was ratified by every member of the United Nations except Somalia and the United States. For details by ratification by state, see U.N. TREATY ColLECTIONS, http://treaties.un.org/Home.aspx?lang=en (follow "United Nations Treaty Series (UNTS) hyperlink; then follow "Title Search" hyperlink; search "Convention on the Rights of the Child"; then follow "See Details" hyperlink for "Convention on the Rights of the Child"). Compliance with the CRC is monitored by the United Nations Committee on the Rights of the Child. Thailand ratified the CRC in 1992 and the optional protocol in 2006. See CRC, supra. Each of the topics mentioned in the poster had its counterpart in the CRC: the right to an education appears in Article 28; the right to health in Article 24; the right to receive information and ideas in Article 17; the right to rest and leisure and the right to participate in cultural life and the arts in Article 31; the right to remain with one's parents in accordance with their wishes in Article 9; the right to protection from sexual exploitation in Article 34; and the right to free expression and the communication of information or views in Articles 12 and 13. See id. 
"down" through planes of legal pluralism. ${ }^{3}$ It represents an important form of transnational research on rights consciousness in the sense that it demonstrates global legal influences in diverse social and political settings and suggests how rights formulated in New York, Geneva, or Beijing can filter down to localized settings-or can be blocked or resisted.

On the other hand, the poster could also be read as an ironic symbol of the chronic disconnection between the legal discourses of the state and the everyday lives and legal consciousness of ordinary citizens-in Thailand and elsewhere. The ideas contained in the poster seemed to bear no relationship to the language, conceptual categories, or practices of the villagers. According to this reading, the poster was an empty symbol, a meaningless gesture by the government, and most likely it endorsed an ideology of rights that the government itself did not sincerely approve. The poster's irrelevance was signified not only by its derelict condition, but also by the fact that it was affixed to the wall of a school building that no longer had either students or teachers.

This second reading, which looks at rights consciousness as it actually manifests itself in everyday interactions within a social arena, stratum, network, or community, could be called the horizontal perspective on transnational legalism. Scholars who conduct horizontal research tend to focus primarily on the shared interpretive practices of ordinary people 4 and the systems of meaning that are familiar to them-within villages, neighborhoods, business networks, trade associations, schools, or other "social fields." 5 The horizontal perspective does not place any particular conceptual framework in the foreground, but through observation and open-ended interviews, asks what discourses are found in particular fields of everyday life and only then considers the origins of key concepts, ideas, and beliefs that it discovers.

3. "Legal pluralism" refers to the coexistence of multiple legal systems-both officially recognized and unrecognized-within a common geographical space. See generally M. B.

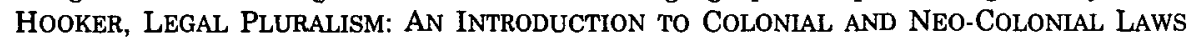
(1975); John Griffiths, What Is Legal Pluralism?, 24 J. LEGAL PLURALISM 1 (1986); Sally Engle Merry, Legal Pluralism, 22 LAW \& SoC'Y REV. 869 (1988).

4. The term "ordinary people" in this Article refers to individuals of all social strata who do not necessarily associate themselves with rights advocacy or rule of law activities. The term is not meant to refer to a particular socioeconomic class or geographical location but rather to a methodology of selection by researchers. In this context, "ordinary people" means individuals who are selected for study on some basis other than their connection to law, legal advocacy, or legal institutions. Thus, they may range from those who are highly rights conscious to those who are less conscious of rights and even to those who affirmatively reject rights.

5. See Sally Falk Moore's discussion of the "semi-autonomous social field" in law and society research, in SALLY FALK MOORE, LAW AS Process: AN ANTHRopological APPROACH 54-81 (1978). 
Generally speaking, the vertical perspective, according to a recent article by Barbara Yngvesson, exists "inside an imaginary of neoliberal culture." 6 The horizontal perspective, however, is found "in what might be considered the constitutive outside of neoliberal culture: the invisible exclusions and nonactions that materialize in the wake of neoliberalism."7

Both the vertical and the horizontal perspectives, as I have defined them, represent essential contributions to the sociolegal study of rights consciousness, and may also be used in conjunction with one another; but I hope to show that their premises are quite different and that they are likely to produce different kinds of conclusions. I shall suggest that a failure to appreciate these differences may lead to erroneous understandings of rights consciousness in the global era and may blind researchers to vitally important developments that are difficult to discern because they run contrary to commonly held assumptions. In considering the symbol of the poster in the schoolhouse, it is important to understand the unique contributions and limitations of both perspectives.

\section{A SHORT HISTORY OF RIGHTS IN THAILAND}

Individual rights consciousness derives from the intersections of a person's life experience with the particular interpretive frameworks that are available in the social environment. The relevance or irrelevance of rights depends in large part on how individuals come to understand their own identities and on the stories they and others tell to make sense of their lives. Individuals continually construct and reconstruct their understandings of self as they interact socially and move forward through new experiences. ${ }^{8}$ This fluid process of identity construction is both internally and externally driven. It is a process of meaning-making through which individuals create a sense of self to

6. Barbara Yngvesson, Border Politics, in The HANDbook of Sociocultural ANTHROPOLOGY (James G. Carrier \& Deborah B. Gewertz eds., forthcoming 2012).

7. $I d$.

8. According to Jerome Bruner, identity construction takes place within a network of family, friends, and acquaintances with whom individuals interact and "distribute" various facets of the self, like using different filing cabinets for important documents. JEROME BRUNER, ACTS OF MEANING 114 (1990). George C. Rosenwald adds that the life story narratives individuals tell themselves and others make meaning of past experiences as well as preparing the way for "new living action." George C. Rosenwald, Conclusion: Reflections on Narrative Self-Understanding, in STORIEd Lives: THE CUlTURAL POLITICS OF SELF-UNDERSTANDING 272-73 (George C. Rosenwald \& Richard L. Ochberg, eds., 1992). The connection between identity construction and rights consciousness is discussed in ENGEL \& MUNGER, supra note 1, at 40-69. 
confront the exigencies of life. Identities, however, are also shaped and constrained by the perceptions of others and by the limited range of interpretive options found in their social surroundings. In addition, different social environments make available different laws, institutions, and procedures, which may be rooted in international, state, local, or nonofficial systems of legality of various kinds. The term rights consciousness refers to the ways in which individuals draw upon, resist, or simply do not consider formal, rights-based legal elements, whether consciously or unconsciously, in their perceptions and behavior. Rights consciousness is recursive in that it both shapes and is shaped by law. Law contributes to identity formation and social interactions, but law is also created and changed by the rights consciousness of those who use or do not use it. Rights consciousness, moreover, is not fixed and immutable. There is not one type of rights consciousness per person. Rather, research shows that an individual's orientation toward rights can be highly volatile and may continually change its form and substance, even in the course of a single conversation. ${ }^{9}$

This Article explores the uses of vertical and horizontal approaches to rights consciousness in the study of transnational law, building its argument on the Thai example with which it began. Before undertaking this analysis, however, it is necessary in this section to provide a sketch of the broader sociolegal environment of which the schoolhouse, the village interviewees, and the northern region of Thailand are a part. Chiangmai is a city and a province in the modern kingdom of Thailand. Founded in the late thirteenth century, Chiangmai has long been regarded as the political and cultural capital of the entire northern region-which is known as Lanna. Chiangmai Province is one of seventy-seven in the modern Thai state, each administered from Bangkok through a complex administrative apparatus that includes courts, constitutions, ${ }^{10}$ and law codes. The origins of the modern Thai legal system are relatively recent. The total transformation of Siam's ${ }^{11}$ premodern legal and political framework took place under King Rama $\mathrm{V}$, who reigned from 1868 to 1910 . Rama $\mathrm{V}$ and his ruling princes redesigned the nation's "irrational" and operationally inefficient legal and administrative structures along European lines and launched a process of legal codification under the supervision of a drafting

9. See ENGEL \& MUNGER, supra note 1, at 12-13.

10. Thailand has had a total of eighteen constitutions since the first was promulgated in 1932. See generally ANDREW HARDING \& PETER LEYLAND, THE CONSTITUTIONAL SYSTEM OF THAILAND: A CONTEXTUAL ANALYSIS (2011).

11. The name "Siam" was changed to "Thailand" in 1939. See David K. WYatT, THAILAND: A SHORT HISTORY 243 (2d ed. 2003). 
committee consisting of Siamese, European, and Japanese specialists. ${ }^{12}$ Legal "modernization" in Siam spanned the late nineteenth and early twentieth centuries and was influenced substantially by. the French, German, English, and Japanese legal systems that were familiar to the Siamese and foreign specialists. Rama V and his princes also established a system of courts within a new Ministry of Justice that must have looked quite familiar to European observers. This was no accident: in this case, familiarity was meant to alleviate rather than to breed contempt. One of the primary aims of the Siamese rulers was to keep the imperial powers, England and France, from entering and colonizing the country under the pretext that they were bringing modern law to an uncivilized and lawless society. ${ }^{13}$

A second aim of the Siamese rulers, which was just as important as the avoidance of colonization, was to fix the boundaries of the new nation-state and to extend Siamese power to the semiautonomous regions of the North, Northeast, and South. The centrally administered legal system and the new legal and administrative codes were crucial for achieving this goal. In Chiangmai's Lanna region, for example, a distinctive legal tradition had long prevailed. Villagers understood legality primarily in terms of conformity to the norms enforced by a hierarchical array of local spirits whose authority extended from the village to the principality. Lanna rulers drew their power and legitimacy in part from their association with these spirits. Over the centuries, a legal tradition had developed that incorporated spirit-based practices into a set of law codes derived from Indian origins. Copies of these law codes, known as Mangraisat (the dharmaśāstras of the

12. See David M. Engel, Code and Custom in a Thai Provincial Court: The INTERACTION OF FORMAL AND INFORMAL SYSTEMS OF JUSTICE 24-29 (1978); APIRAT Petchsiri, Eastern Importation of Western Criminal LaW: ThaIland as a Case

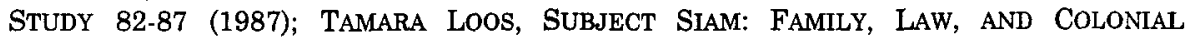
MODERNITY IN THAILAND 59-63 (2006).

13. Law reform under Rama $V$ was "the arena in which Siam's leaders had to prove the country's modernity." Loos, supra note 12, at 43 . Creation of a modern legal system represented a "strategy of control that helped Siam's leaders claim Siam's status internationally as fully sovereign." Id. at 45 . 
legendary Lanna founder, King Mangrai), ${ }^{14}$ have been found in temples throughout northern Thailand. ${ }^{15}$

The "modernization" of Siamese law, led by Rama V and his successors, should therefore be understood as part of a project designed, among other things, to curb the power of the traditional Lanna rulers through administrative reform and to replace the Mangraisat with a European-style legal regime that could be controlled directly from Bangkok. The modern discourse of rights entered Siam with the enactment of these law codes in the early twentieth century. For example, The Civil and Commercial Code refers to the rights of natural and juristic persons (Sections 66-67), ${ }^{16}$ certain rights of debtors and creditors (Sections 198 and 200), ${ }^{17}$ the rights and duties of mortgagees and mortgagors (Sections 722-727), ${ }^{18}$ and various property rights (Section 1298). ${ }^{19}$ The Thai Penal Code refers to an individual's right to reasonably defend himself or herself (Section 68). ${ }^{20}$ The Thai Criminal

14. A dharmaśāstra, known in Thai as thammasat, is a law text in the classical Indian Hindu-Buddhist tradition. According to J. Duncan M. Derrett, Dharmaśāstra means 'the teaching (or science) of righteousness,' and includes what the modern European understands by 'law,' without, however, exhausting that topic . . . . India, in reality, shares with Islam and with Judaism the belief that righteousness is an independent science of greater importance than mere day-to-day administration, and that ... judges, arbitrators, or others, ... . would, if properly educated in righteousness, tend or endeavor to give a just decision. J. DUNCAN M. DERRETT, DHARMAŚs̄STRA AND JURIDICAL LITERATURE 2 (1973).

15. See generally THE LAWS OF KING MANGRAI (MANGRAYATHAMmasarT) (Aroonrut Wichienkeeo \& Gehan Wijeyewardene eds. and trans., 1986); A. B. Griswold \& Prasert na Nagara, Epigraphic and Historical Studies, No. 17: The 'Judgements of King Man Ray', 65 J. SIAM Soc'Y 137 (1977); David K. Wyatt, Law and Social Order in Early Thailand: An Introduction to the Mangraisat, 15 J. SOUTHEAST ASIAN STUD. 245 (1984).

16. Unofficial texts of Thai law codes, including the Civil \& Commercial Code, can be accessed online. See, e.g., THAILAWS, http://thailaws.com/ (last visited May 26, 2012). "A juristic person has rights and duties conformity with the provisions of this Code or of other law within the scope of its power and duties, or its object as provided by or defined in the law, regulation or constitutive act." CIV. \& COMM. CODE $\$ 66$ (2008) (Thai.), available at http://thailaws.com. "Subject to Section 66, a juristic person enjoys the same rights and is subject to the same duties as a natural person." $I d$. $\S 67$.

17. "If several acts of performance are due in such a manner that only one of them is to be done, the right to elect belongs to the debtor unless otherwise stipulated." Id. $\$ 198$. "If the election is to be made within a period of time, and the party who has the right of election does not exercise it within such period, the right of election passes to the other party ...."Id. $\S 200$.

18. Id. $\S \S 722-27$.

19. "Real rights may be created only by virtue of this Code or other laws." Id. $\$ 1298$.

20. Any person is to commit any act for defending his own right or other person's right in order to except from a danger arising out of violence tortuous to the law and such danger to be imminent, if reasonably having committed under the circumstance, such act is lawful defense, and such person shall not have a [guilt]. CRIM. CoDE $§ 68$ (2003) (Thai.) available at http://thailaws.com. 
Procedure Code specifies the right of a married woman to refer a criminal charge without her husband's permission (Section 4), ${ }^{21}$ the right of an injured person to bring criminal charges even when the prosecutor has declined to do so (Section 34), ${ }^{22}$ and the right of an injured person to bring a civil suit even when a criminal prosecution has been undertaken (Section 45). ${ }^{23}$

The language of rights also appears in the codification of Thai tort law, which is the primary focus of my research. For example, Title V ("Wrongful Acts") of the Civil and Commercial Code contains many references to rights, including: Section 421 ("The exercise of a right which can only have the purpose of causing injury to another person is unlawful"), ${ }^{24}$ Section 446 (nontransferability of the right to make a claim for nonpecuniary loss), ${ }^{25}$ Section 448 (the effect of prescription on the right to bring a tort claim), ${ }^{26}$ and Section 451 (justifiability of the use of force to protect a legal right). ${ }^{27}$

The concept of rights within the modern Thai legal system received further definition when the absolute monarchy was overthrown in 1932 and the first of a long series of constitutions was enacted. For example, Chapter II of the Siamese Constitution of 1932 referred to the "Rights and Duties of the Thai People,"28 including rights of equality, religion, person, property, speech, and others:

21. "In a criminal case, if victim is a [married woman], she shall be entitled to institute a prosecution by herself without having to obtain permission of her husband . . . " CRIM. PROC. CODE $§ 4$ (2008) (Thai.) available at http://en.wikisource.org/wiki/Criminal_Procedure _Code_of_Thailand/Provisions.

22. "An order of non-prosecution does not prejudice the victim's right to institute a prosecution by himself." Id. $\$ 34$.

23. "The fact that a prosecution against any offence has been instituted does not prejudice the victim's right to bring a penal action on the basis of such offence also." Id. $\S$ 45.

24. Crv. \& COMM. CODE $§ 421$ (2008) (Thai.), available at http://thailaws.com.

25. In the case of injury to the body or health of another, or in the case of deprivation of liberty, the injured person may also claim compensation for the damage that is not pecuniary loss. The claim is not transferable, and does not pass to the heirs, unless it has been acknowledged by contract, or an action on it has been commenced. Id. $\S 446$.

26. "The claim for damages arising from wrongful act is barred by prescription after one year from the day when the wrongful act and the person bound to make compensation became known to the injured person, or ten years from the day when the wrongful act was committed." Id. $§ 448$.

27. A person who uses force for protecting his rights is not liable to make compensation if under the circumstances the help of the Court or of the proper authorities is not obtainable in due time and there is danger that, if he does not act immediately, the realization of his right will be frustrated or seriously impeded. Id. $\S 451$.

28. Thai Politics: ExTracts AND Documents 1932-1957, 99 (Thak Chaloemitiarana, ed., 1978). 
Section 12. Subject to the provisions of this Constitution, all persons are equal before the law. Titles acquired by birth, by bestowal or in any other way do not confer any privilege whatsoever.

Section 13. Every person enjoys full liberty to profess any religion or religious creed, and to exercise the form of worship in accordance with his own belief, provided that it is not contrary to his civic duties or to public order or good morals.

Section 14. Subject to the provisions of law, every person enjoys full liberty of person, dwelling, property, speech, writing, publication, education, public meeting, association and profession. ${ }^{29}$

Sixty-five years and sixteen constitutions later, the so-called People's Constitution of 1997 represented a high-water mark of constitutional rights in Thailand. This admirable document, produced by a large and diverse drafting committee, emerged from nationwide public consultation in which "countless regional local hearings were organized to discuss the scope of the enterprise and many fundamental issues were pondered, debated, drafted, re-drafted and finally decided upon."30 The 1997 Constitution articulated a broad array of rights. Indeed, the entirety of Chapter 3 (Sections 26-65) is devoted to an enumeration of the Rights and Liberties of the Thai People, including: rights of gender equality (Section 30), rights against torture, brutality, or cruel and inhumane punishment (Section 31), the right to a presumption of innocence in criminal proceedings (Section 33), rights of religious freedom (Section 38), rights of free expression (Section 39), the right to at least twelve years of education (Section 43), the right of peaceful assembly (Section 44), the rights of traditional communities to "conserve or restore their customs, local knowledge, arts, or good culture of their community" (Section 46), and many others. ${ }^{31}$ Although this remarkable document was abrogated after the coup of 2006 and replaced with Thailand's eighteenth constitution in 2007 , at least one commentator has observed that its spirit and many of its core provisions did not simply disappear, but have experienced a "constitutional

29. Id. at 99 .

30. B.J. TERWIEL, THaIland's Political History: From the Fall of AYUTTHAYA to RECENT TIMES 289 (2005). See generally HARDING \& LEYLAND, supra note 10, at 22-24.

31. CONSTITUTION OF THE KINGDOM OF THAILAND (1997). 
afterlife" and can be expected to reappear in future documents. ${ }^{32}$ Indeed, the government of the Pheu Thai party, elected in July 2011 and led by Prime Minister Yingluck Shinawatra, favors amending the 2007 constitution to return to the spirit or even the letter of the 1997 constitution. ${ }^{33}$ If a new constitution emerges from this process, it will be the nineteenth since 1932.

Recent articulations of constitutional rights in Thailand derive not just from internal debates and political movements, but also reflect transnational constitutional influences, such as the trailblazing processes of public participation in countries such as South Africa. ${ }^{34}$ Transnational influences on rights discourses in Thailand have also been introduced through Thailand's accession to various international treaties such as the CRC, through Thailand's obligations as a member of the Association of Southeast Asian Nations (ASEAN), through the programs of the World Bank and the United Nations, and through the advocacy work of NGOs. As we have seen in the example of the children's rights poster, the Thai government at times disseminates transnational rights concepts, but when the government does not promote such rights-or even when it actively opposes them-the mass media and the Internet can continue to familiarize ordinary people with them through news coverage, opinion pieces, and blogs. Furthermore, Thai political parties, cause lawyers, ${ }^{35}$ and activists may invoke rights discourses as they pursue power or social change.

\section{Problematizing Rights Consciousness}

With the expansion and proliferation of rights concepts in Thailand over the course of the twentieth century, the question of rights consciousness is of more than academic interest. It has become

32. See Tom Ginsburg, Constitutional Afterlife: The Continuing Impact of Thailand's Postpolitical Constitution, 7 INT'L J. Const. L. 83, 84 (2009).

33. See Aekarach Sattaburuth, Govt Vows Push to Revise Charter, BANGKoK POST (Aug. 24, 2011) (Thai.), http://www.bangkokpost.com/news/politics/253145/govt-vows-pushto-revise-charter. Recent statements by the Pheu Thai leadership have appeared to support amendment rather than wholesale abrogation of the 2007 constitution. See PM: No Change to Monarchy Law, BANGKoK PosT (Feb. 29, 2012) (Thai.), http:/www.bangkokpost.com/news/politics/282186/pm-no-change-to-monarchy-law.

34. See Jeremy Sarkin, The Drafting of South Africa's Final Constitution from a Human-Rights Perspective, 47 AM. J. CoMP. L. 67, 69-72 (1999) (including in the process of public participation education campaigns and public submissions).

35. See Frank Munger, Globalization, Investing in Law, and the Careers of Lawyers for Social Causes: Taking on Rights in Thailand, 53 N.Y.L. SCH. L. REv. 745, 802 (2009) (suggesting that cause lawyers in Thailand engage in "ambiguous, Thai-style collaboration with government," which "blends the rule of law with the social relationships they value, creating a new culture of governance and opportunities for change"). 
important to know how far ordinary people ${ }^{36}$ have gone toward incorporating these ideas about rights into their thoughts and actions, and to what extent rights have actually shaped the identities of citizens throughout Thailand. Unfortunately, this question has not received systematic attention from socio-legal scholars and remains difficult to answer. Certainly the expression of rights has featured prominently in some of the most important political events of the past half-century, including those unfolding at the present time. Yet, the leaders of Thai political movements are not typical of the general citizenry, and their invocation of rights may not reflect how ordinary people interpret their experiences and identities.

Socio-legal research literature extending over more than half a century has taught us to be skeptical of the assumption that rights or other legal concepts inevitably migrate from law books to the law in action and has provided countless examples of laws that are ineffective, ignored, evaded, manipulated, or are otherwise irrelevant to those at whom they were targeted. In light of this distinguished research tradition, few observers familiar with socio-legal scholarship would assume a simple or direct relationship between the proliferation of formal rights in Thailand and the consciousness or behavior of ordinary Thai citizens. Nevertheless, discussions of Thai law in the global era typically highlight these new laws and legal institutions and either assert or imply that they must signify something, that some sort of grassroots change in rights consciousness must be in progress, and the development of laws, legal institutions, and law-related activism must play some role in individual thought and action. Yet the connection between transnational legal practices, the expansion of formal rights within Thailand, and the consciousness of ordinary citizens has, for the most part, been either assumed or ignored as a problem worth exploring.

My own research in northern Thailand from the 1970s to the present suggests that a closer scrutiny of the rights consciousness of ordinary people may yield some surprising results. My research was not focused on high profile rights concepts grounded in Thai constitutional developments or in the international human rights corpus, since asking people directly about those issues might bias their responses in favor of a rights-based discourse. The aim of research on rights consciousness is to detect its presence or absence in the thoughts and actions of individuals across a range of social interactions. Research that injects into the interview the very concepts whose existence is being researched would be methodologically self-defeating.

36. See supra note 4 for definition of the expression "ordinary people." 
I attempted to avoid this problem in two ways. First, I chose a subject matter-physical injuries-that does not necessarily fall inside the ambit of "the imaginary of neo-liberal culture." 37 Injuries can be understood within the framework of rights analysis or entirely separate from it. Second, I did not ask interviewees directly about the legal implications of the injuries they suffered but instead invited them to narrate their life stories and to situate their injury experience within the flow of events from childhood to the present. As they constructed their narratives, I listened and attempted to discern when and whether they themselves referred to law and legal rights. By encouraging the interviewees to frame their accounts using terms and concepts of their own choosing, I was able to identify the situations in which law and legal rights were absent as well as when they were present.

The results, which I have described more extensively elsewhere, ${ }^{38}$ were surprising and counterintuitive. I had previously conducted research in Chiangmai in 1975, just forty years after promulgation of the Thai Civil and Commercial Code and forty-two years after passage of the first Thai Constitution. My 1975 study of court transcripts, observation of judicial proceedings, and interviews with village leaders, litigants, lawyers, and others, led me to conclude that at that time the formal legal system interacted in complicated, but unacknowledged, ways with a still-vibrant system of customary laws and practices. ${ }^{39}$ Ordinary people preferred to stay away from lawyers and official legal institutions, sometimes citing the familiar aphorism, "It is better to eat dog shit than to go to court." 40 Most disputes, including injury cases, were resolved through informal mediation by village authority figures. ${ }^{41}$ Disputants believed that the locality spirits of the village and the principality were offended by wrongful acts, and injury victims demanded for the good of the community that the injurer pay restitution and provide resources to perform ceremonies to appease the spirits..$^{42}$ Occasionally customary negotiations would break down, and in such instances, the injured party might consider litigation. ${ }^{43}$ Fellow villagers understood the choice to step outside the bounds of customary dispute resolution, because they saw it as another way to enforce the demands

37. Yngvesson, supra note 6.

38. See generally David M. ENGel \& JaRuWAN S. ENGel, ToRT, Custom, and Karma: GLOBALIZATION AND LEGAL CONSCIOUSNESS IN THAILAND 95-122 (2010).

39. Id. at 78. Interviews referenced in this Article were conducted in Thai by the author, with Jaruwan S. Engel. Tapes and Thai language transcriptions are on file with the author.

40. This expression was recited repeatedly during the initial fieldwork.

41. ENGEL \& ENGEL, supra note 38 , at 78 .

42. Id. at 56-66.

43. Id. at 78 . 
of the spirits. ${ }^{44}$ Typically, the plaintiff would withdraw the suit when the injurer agreed to a settlement, and it was evident in some cases that the settlement amount had been determined with reference to customary norms rather than the provisions of the law codes..$^{45}$

Thus, in the 1970s, the Chiangmai Provincial Court was an institution typically avoided but occasionally used for goals rooted in the cultural history of Lanna. The place of litigation in the broader dispute resolution system was widely understood if not universally approved. Yet nowhere did I observe ordinary people actually embracing the concept of rights. They did not invoke the law to vindicate their rights but to promote norms and practices that could be traced back to premodern Lanna, to spirit worship, and even to the provisions of the Mangraisat.

I returned to Chiangmai twenty-five years later to assess the rights consciousness of ordinary citizens during an era of intense global influences and extensive social, economic, and demographic change at the turn of the twenty-first century. Consistent with the popular assumptions about expanding rights consciousness outlined above, I expected to find that injury victims used official law more readily and referred to their rights rather than adhering to customary beliefs and practices. Specifically, I thought my focus on injury litigation would match the headlines of Thai newspapers and yield a bounty of tort cases dealing with medical malpractice, automobile accidents, toxic exposures, products liability, and the like. But none of these expectations were met either in my study of court documents from 1992 to 1997 or in my interviews with persons treated for serious injuries in a large Chiangmai hospital. Available data suggested that injury litigation rates had, if anything, declined since my earlier research in the 1970s. This conclusion was suggested by two related findings. First, it appears that most injuries in Chiangmai are caused by traffic accidents. 46 Second, although the number of traffic-related injuries from the 1960s to the 1990 s could not be reliably determined, I did find that the number of motor vehicles registered in Chiangmai from 1965 to 1997 had increased by nearly 800 percent. 47 The enormous increase in vehicles on the highways served as a plausible indicator that the

44. Id.

45. Id.

46. In my hospital sample of 93 patients, which included nearly all injury victims admitted to one of the major hospitals in Chiangmai Province over a three-month period, 75.3 percent were injured in traffic accidents.

47. From 1965 to 1997 , the number of registered motor vehicles in Chiangmai Province increased from 8,547 to 677,123. Samut Raingan Satiti Jangwat Chiangmai [Statistical Reports of Chiangmai Province], NAT'L STAT. OFF. THAI. (1966-1998). 
number of vehicle-related injuries, and hence the number of injuries overall in Chiangmai, must have increased substantially as well. Yet the number of tort cases per thousand people had actually remained about the same- 0.071 cases from 1965 to 1974 and 0.088 cases from 1992 to 1997.48 This means that the litigation rate per injury, tort cases divided by injuries, had very likely declined over the last thirty years of the twentieth century. The decrease is especially striking if we look only at personal injury lawsuits and exclude tort actions merely involving property damage. On average, from 1992 to 1997, out of a population of more than 1,300,000 people, only eleven personal injury cases per year were litigated in the Chiangmai Provincial Court. 49

Interviews with injury victims substantiated this picture of a decline in claims. The interviewees made it clear that when ordinary people suffered serious injuries, they considered the assertion of their legal rights to be irrelevant and contrary to Buddhist teachings. None of them consulted a lawyer, filed a tort action, or prosecuted a private criminal case. ${ }^{50}$ At the same time, they had become unfamiliar with village-level customary law and were unable to apply it in nearly all cases. Obtaining a remedy of any kind from the injurer had become highly problematic.

What caused this dramatic change in Lanna legal culture, and what had become of the unspoken but important connection between customary practices and state law? Global influences transformed Lanna society in the final years of the twentieth century. ${ }^{51}$ During the $1980 \mathrm{~s}$ and 1990s, the Thai export-oriented economy boomed, foreign direct investment increased, and the country became a prime tourist destination. ${ }^{52}$ These socioeconomic changes dramatically affected Lanna. Many younger workers, as we have already seen, left their villages to take up wage labor in the city of Chiangmai or in Thailand's central region. Farmland was sold and turned into housing developments, industrial estates, and shopping centers. ${ }^{53}$ Although

48. ENGEL \& ENGEL, supra note 38, at 102.

49. Id. at 106 .

50. The Thai Criminal Procedure Code, Section 28, permits the victim to bring criminal charges even when the public prosecutor has declined to pursue a case, and some personal injury victims took advantage of this opportunity. During our earlier research, in which we surveyed the docket of the Chiangmai Provincial Court in 1965, 1968, 1971, and 1974, we discovered 8.25 private criminal cases per year involving injury claims. During our later research, however, in which we surveyed the docket from 1992 to 1997, we found only 1.33 such cases per year. $I d$. at 108 . This represents a very substantial drop in the use of private criminal prosecutions by personal injury victims.

51. Id. at $40-45$.

52. Id. at $42-44$.

53. Id. at 44 . 
nearly three-quarters of Chiangmai's citizens still reside in rural settings, ${ }^{54}$ most of the interviewees in our study lived far from their birth villages and described themselves as cut off from the practices, beliefs, and rituals that had shaped the lives of their parents and grandparents. As one injury victim, a middle-aged woman named Saikham, ${ }^{55}$ explained:

If we followed the old customs, that would be good. But we don't know how to do it now. Because we, how should I say it, we have entered the modern world now. How can I explain this? The old ways have ended; we don't know how to do these things. I like them, but I can't do them.

Lanna legal culture has changed, according to our interviewees, because injuries no longer occur in integrated village communities. They no longer offend the guardian spirits. Injury victims do not believe that the injurer's misconduct affects anyone but themselves. Identity has become more sharply individuated, and injuries and remedies have lost their relational and communitarian qualities. While injury victims might still hope to receive some form of compensation from their injurers, no one else is thought to have a direct stake in making sure that the injurer provides a remedy. Community pressure on the injurer to comply with customary law has all but disappeared. Local mediators have no authority over disputants who live outside the village.

In the past, spirit worship at the village level was closely linked to Buddhist beliefs and practices. ${ }^{56}$ Buddhism remains strong, but it is no longer tied to particular localities. Buddhist practices, according to our interviewees, have become more universalized-accessed by radio, television, books, DVDs, and the Internet. Injury victims invariably thought their misfortune had been caused by their own karma. For

54. See Key Indicators of the Population and Households: Population and Housing Census 1990 and 2000, NAT'L STAT. OFF. THAI., http://web.nso.go.th/pop2000/finalrep/ cheingmaifn.pdf (last visited Dec. 18, 2011).

55. Interviewees quoted in this Article are identified by pseudonyms in order to protect guarantees of confidentiality offered to them during the fieldwork. The original round of interviews took place from June to August, 1999. Follow-up conversations with selected interviewees, including Buajan, Part IV infra, took place in January 2010.

56. For descriptions of the linkages between spirit worship and Buddhism in Thailand, see generally, RICHARD DAVIS, MUANG METAPHYSICS: A STUDY OF NORTHERN THAI MYTH and Ritual (1984); Charles F. Keyes, The Golden Peninsula: Culture and ADAPTATION IN MAINLAND SOUTHEAST ASIA (1977); SHALARDCHAI RAMITANON, PHI JAO NAI [SPIRITS OF THE NOBILITY] (2002); S.J. TAMBIAH, BUDDHISM AND THE SPIRIT CULTS IN NORTH-EAST THAILAND (1970). 
example, one young man believed his injury occurred because of bad karma he created when he worked in a slaughterhouse. A middle-aged woman injured by a negligent driver thought her leg was broken because she had beaten a dog with a stick and broken its leg. ${ }^{57} \mathrm{~A}$ farmer traced her motorcycle accident to the gardening work she did with her husband-when they tilled the soil they must have inadvertently injured or killed the tiny creatures that lived underground.

Some interviewees stated that they were suffering now because of sins committed in a previous life. In fact, they may have injured their injurers in their former existence. The cycle of injury and counterinjury would continue through many lifetimes unless one of them ended the suffering by practicing the Buddhist virtues of compassion and mercy. Rather than insist on a remedy, they thought it was better to acknowledge the karmic origins of their misfortune and forgive the injurer. In this way, they could protect themselves and their family members against future harm more effectively than by seeking monetary compensation.

There was nothing new about interpreting one's injuries in terms of karma. ${ }^{58}$ But these injury narratives were unprecedented in that Buddhist frameworks had now separated completely from village-based remedy practices based on spirit worship. Buddhism, cut loose from spirit worship, seemed to the interviewees to require them to absorb the injury without any demand for substantial compensation from the injurer. As one interviewee told us:

People in Lanna, maybe we just have meritorious spirits. That's just how we are. If something is destined to happen, then we just let it go. This has to do with our moral code, the ethics we learned in school when the religious teachers instructed us . . Buddhism teaches people to do only good, and we keep that sort of thing in our minds at all times. That's why our society is like this.

57. This case, involving a woman I call "Buajan," will be discussed in greater detail in Part IV infra.

58. The teachings of Theravada Buddhist monks in the thirteenth and fourteenth centuries had emphasized the connection between karma and human suffering of all kinds. The concept of karmic causation has remained fundamental to Thai Buddhism. KEYES, supra note 56, at 90. See also, Peter A. JACKSON, BudDHADĀsa: TheravadA BUDDHISM AND MODERNIST REFORM IN THAILAND 20 (2003) (Thai Buddhism has generally emphasized karma and "correct action" in order to achieve "right results."). 
Interviewees agreed that injuries caused by the victim's own bad karma should be addressed by adherence to Buddhist teachings. The aggressive pursuit of a remedy will only perpetuate suffering and cause more conflict and pain in the future.

Contrary to what one might expect, the disappearance of a customary law of injuries at the village level did not lead to an increase in rights claims among the interviewees in this study. Although injury cases were no longer resolved at the village level, injury victims did not view official Thai law as an acceptable substitute for village customary law. The modest stream of litigated injury cases in the 1960s and 1970s was reduced to a trickle by the late 1990s. None of our hospital interviewees resorted to the formal legal system. The discourse of rights has not emerged as a substitute for traditional Lanna legal discourses.

\section{VERTICAL AND HORIZONTAL PERSPECTIVES}

Why is it that popular assumptions about the expansion of rightsbased norms and institutions during this global era do not accurately describe the rights consciousness of ordinary people in northern Thailand? Why does the distinctive transformation of social norms and legal-religious ideology I encountered in my research tend to fly beneath the radar, leading to wholly unexpected developments in a society that appears on the surface to be moving steadily in the direction of liberal legalism? What tools of socio-legal research are available to detect and measure such counterintuitive changes?

There can be no question that law and society researchers have entered the global age and are now seeking new ways to study a world in which formal laws and legal institutions can no longer be associated exclusively-or even primarily-with the nation-state. Studies of transnational, subnational, or anti-national legal practices and institutions have undermined the exclusive identification of the state with the law that we study. The expression "law and society" itself has become uncertain. We cannot assume that "law" refers either to state law or to alternative localized systems of customary practice and dispute resolution. We cannot assume that "society" refers to clearly bounded local communities or to national groups-Japanese society, Italian society, American society, or Thai society-which were often the intended referents of law and society scholars. Today, "society" may just as well apply to transnational fields of interaction, relational networks, or international organizations.

Some of the most interesting and exciting work by socio-legal scholars in recent years explores this broader and more complex global 
understanding of legal institutions, practices, actors, and influences. ${ }^{59}$ One of the recurring foci is the role of rights, which are presumed to be the essential foundation of modern law. ${ }^{60}$ Much of this research reflects what I have called a vertical perspective. That is, it attempts to theorize and sometimes to offer empirical descriptions of the transnational flow of liberal legal norms, institutions, and practices, and it asks under what circumstances such flows are facilitated or impeded at the national, subnational, or local levels.

One insightful review of this type of research is offered by Terence C. Halliday and Pavel Osinsky, ${ }^{61}$ who suggest that "a theory of legal globalization" must focus both on the key actors who "create, propagate, and receive global norms and organizations" and on the locales in which these activities take place: "it will explicate where global norms and templates originate and how they are conveyed to sites across the world where they are differentially integrated into local institutions and practices."62 Researchers, according to Halliday and Osinsky, must consider not only the internal dynamics of this process but also the resistance it encounters along the way. For example, "[1]iberal constitutionalism" confronts such obstacles as "[1]ocal political elites, 'Big Man' regimes in Africa, authoritarian rulers, military dictators, and religious hierarchies . . ."63 Thus, the authors conclude, observers must always be skeptical "about excessive claims made of globalization and its impact" and must remain aware of "the rampant contingency of globalization."64

Two features of this nuanced treatment of legal globalization are worth noting in the context of our analysis of the distinctive features of the vertical perspective: First, the research question is posed in terms of "impact." Liberal legalism is the active agent and the societies of the global south are the potential recipients of this dynamic force. The question is, therefore, the readiness of actors in these societies to accept these legal practices, and the conditions that are required for acceptance to occur. Second, the factors that prevent acceptance tend to be constructed negatively as irrational and undemocratic-such as "Big Men," despots, or theocrats.

59. See, e.g., Terence C. Halliday \& Pavel Osinsky, Globalization of Law, 32 ANN. REV. OF SOC. 447 (2006).

60. See, e.g., Jean-Marc Coicaud, Conclusion, in The Globalization of HuMAN Rights 178, 193 (Jean-Marc Coicaud, Michael W. Doyle \& Anne-Marie Gardner eds., 2003) ("Law is based upon the recognition and implementation of rights.").

61. Halliday \& Osinsky, supra note 59.

62. Id. at 450 .

63. Id. at 464 .

64. Id. at 466 . 
This form of research, as Halliday and Osinsky characterize it, is not designed to ask how ordinary people in societies of the global south may be working actively rather than passively to construct alternatives to liberal legalism; nor does vertical perspective research in itself attempt some independent evaluation of whether the alternatives they devise are invariably less beneficial than rights-based regimes. The lack of attention to alternative legalities external to liberal legalism may result in part from the exhaustion of a lengthy debate over cultural relativism versus universality in the human rights field, as well as a widespread rejection of the self-serving argument of "Asian values" put forth by repressive and undemocratic regimes in Southeast Asia and elsewhere in the region. But it is not necessary to embrace relativism or so-called Asian values to raise the empirical question of how ordinary people actually think and behave.

Research reflecting the vertical perspective has opened new vistas for the field of law and society and has fundamentally redefined many of our central terms and topics. Yet our enthusiasm for studies of this kind is not always accompanied by a clear sense of what vertical methodologies can and cannot tell us about rights consciousness within the general population. In particular, the vertical perspective in itself provides no check on the assumption that transnationalism has necessarily brought an increase in the role of law in everyday life (except when impeded by antidemocratic obstacles), an assumption fueled by the mass media and popular mythology as well as by some scholars. As the Thai example suggests, the actual situation may be quite different. It is one thing to suggest that legal ideas, institutions, and practices can travel from the global North to the global South, from the centers of cultural production in Europe and North America to societies that are portrayed as the recipients of the ideas and institutions of liberal legalism. But it is quite another thing to conclude that they tend to take root and flourish once they arrive or to predominate over the legal orders they encounter. Moreover, the characterization of so-called receiving nations as relatively passive when it comes to cultural production can be highly misleading, since many of these same countries have produced some of the most dynamic forms of legality, or antilegality, in our era. Thailand is a case in point.

A related problem is that very often those who advocate the transnational expansion of rights tend to provide their own narrative about the inevitability of a growth in rights consciousness. Such narratives certainly merit scholarly attention, but should they necessarily be taken as descriptively valid? For example, in a much quoted speech delivered to the U.N. General Assembly in 1999, thenSecretary-General Kofi Annan described "a world transformed by geo- 
political, economic, technological and environmental changes" and contended that, in that world,

[t] he State is now widely understood to be the servant of its people, and not vice versa. At the same time, individual sovereignty-and by this I mean the human rights and fundamental freedoms of each and every individual as enshrined in our Charter-has been enhanced by a renewed consciousness of the right of every individual to control his or her own destiny. ${ }^{65}$

What exactly is this statement meant to convey about the status of rights consciousness in a transnational world? Annan is hopeful and supportive of the spread of rights globally, but he also offers an empirical claim about changes that are occurring on the ground, changes that could be observed in the minds and practices of people who live in villages and neighborhoods around the world. What would be the basis for this empirical claim and how could it be substantiated? Annan's statement finds its counterpart in the writings of many scholars who study transnational legal phenomena. For example, Lawrence Friedman and Rogelio Pérez-Perdomo, in their book on global influences in Latin America and Latin Europe, observe, "[e]xposure to foreign influences weakens the links of local culture, evades tradition, accentuates individualism, and increases resort to law for the affirmation of individual rights." 66 The line between the hortatory and inspirational language of the Secretary-General and the analytic language of socio-legal scholars who study these processes can become blurred, but whether the observer's purpose is prescriptive or descriptive, it is evident that the vertical perspective alone cannot do the job.

The innovative work of Sally Engle Merry on transnational human rights and gender violence provides a helpful example of the uses and limitations of the vertical perspective in the hands of a scholar who is sensitive to the issues raised in this Article. In a recent book, ${ }^{67}$ Merry

65. Kofi Annan, Secretary-General Presents His Annual Report to the General Assembly (Sept. 20, 1999), http://www.un.org/News/ossg/sg/stories/statments_search_ full.asp?statID $=28$ (last visited Dec. 18, 2011).

66. Rogelio Pérez-Perdomo \& Lawrence Friedman, Latin Legal Cultures in the Age of Globalization, in LEGAL CULTURE IN THE AGE OF GLOBALIZATION: LATIN AMERICA AND LATIN EUROPE 5 (Lawrence M. Friedman \& Rogelio Pérez-Perdomo eds., 2003) (citations omitted).

67. Sally ENGle MerRy, Human Rights and Gender Violence: Translating INTERNATIONAL LAW INTO LOCAL JUSTICE (2006). 
presents what she calls a "deterritorialized ethnography" 68 focusing on a single human rights topic-gender violence-in its transnational legal context. Merry's research took her from U.N. agencies in North America and Europe to NGO offices and conferences in various world regions, as well as to grassroots activists in Asia and the Pacific. Her research was vertical in the sense that it traced the movement of a concept-that women have rights under international law, which are violated when they are subjected to gender violence-from the most lofty and overarching levels of legal production to the local level of village practices.

Studies of this kind spatialize law in a distinctive way, mapping it in terms of higher and lower regions. Typically, the higher regions are associated with greater power and influence and with postEnlightenment ideas about law. Their influence tends to flow downward rather than upward, from rational, rights-based concepts of law to localized settings in which non-Enlightenment ideas about law hold sway. The spatialization and directionality of this research model explain my use of the term vertical to describe it. Merry, of course, is fully aware of the cultural assumptions that underlie this framework and is careful to account for them in her analysis. ${ }^{69}$ We might go one step further, however, and suggest that the vertical model also has an implicit normative preference. Those who adopt it tend to assume that rights are right. Merry critiques the universalism-relativism debate of the $1990 \mathrm{~s}^{70}$ and attempts to go beyond it, yet in doing so she explicitly incorporates in her analysis some of the same prorights values as the actors she studies. While proceeding carefully and remaining sensitive to the problems of cultural hegemony, Merry concludes with a thoughtful but firm endorsement of the very flow of rights concepts that she documents ethnographically:

Despite drawbacks in the way the concept of human rights has been developed and used, it is still the only global vision of social justice currently available. With all its flaws, it is the best we have. It provides at least some constraint on the operation of markets and offers a potentially powerful tool to those who learn to use it. Like the language of law itself, it serves those in power

68. See id. at 28-30.

69. See, e.g., id. at 1.35 (providing a nuanced discussion of "culture and transnationalism").

70. See id. at 8 . 
but is always in danger of escaping its bounds and working in a genuinely emancipatory way. ${ }^{71}$

If I am correct that the vertical model reflects both a distinctive spatialization of law in the global era and a normative preference for the cultural flows it documents, what is the result of research that relies on this model? More specifically, what can it tell us about the rightsconsciousness of ordinary people? Merry's study is exemplary in this regard, since she considers both the heuristic power and the limits of the vertical research model..$^{72}$ In brief, she argues that the downward dissemination of rights consciousness leads to a double bind. ${ }^{73}$ To become effective at the local levels, rights must be translated into discourses familiar to ordinary people. Yet the problem faced by rights advocates is that too much translation or adaptation will neutralize rights and deprive them of the power that derives from the very fact of their externality in relation to the local culture:

To blend completely with the surrounding social world is to lose the radical possibilities of human rights. It is the unfamiliarity of these ideas that makes them effective in breaking old modes of thought.... On the other hand, it is only when they take a familiar form that they are readily adopted. ${ }^{74}$

If rights must be translated and adapted to become active at the grass roots level, yet must also retain their unfamiliarity and externality, what is the likelihood that ordinary people will actually incorporate them into their legal consciousness? What are the chances that individual identities and life narratives will reflect the influence of rights? The methodology of Merry's study does not attempt to measure the popular acceptance of rights within the locales she studies, but she does offer some cautionary observations. She notes that the translation of international human rights in particular localities "occurs at a relatively superficial level, as a kind of window dressing." 75 She adds

71. Id. at 231.

72. See, e.g., id. at 29 ("The challenge is to . . track the information flows that constitute global discourses, and to mark the points at which competing discourses intersect in the myriad links between global and local conceptions and institutions .... This is hard to pull off on a global stage.").

73. Id. at 221 ("The failure to fully indigenize these ideas [of gender equality and freedom from violence] impedes their spread, yet to do so would undermine their potential to challenge social inequalities.").

74. Id. at 178.

75. Id. at 177 . 
that "the impact is greater on transnational elites and middle-level NGO activists than on people at the grass roots." 76 Elsewhere, she has observed, "[a]s translators vernacularize these transnational institutions and ideas, they promote this modernist view, with its emancipatory and homogenizing effects. Whether or not they achieve an expanded human rights subjectivity is far more uncertain." 77

In deploying the vertical model of research on transnational law, Merry is careful not to make unwarranted claims about the rights consciousness of ordinary people that would exceed the methodological limits of her research design. Yet it is difficult for scholars and other observers-most of whom (myself included) share the normative preference for widespread rights dissemination-to avoid implying that the vertical phenomena they document are associated with an expansion of rights along a horizontal axis. It is easy to imagine a researcher in this tradition selecting Chiangmai as a site for the study of transnational human rights and local activism. In Chiangmai, the researcher would find dozens of NGOs working energetically in many different ways to translate rights into local discourses and thereby promote the ideology of liberal legalism. Some NGOs are aimed at the protection of women's rights, including the prevention of domestic violence, which is the subject of Merry's research. 78 Others address a plethora of rights concerns, such as the rights of migrant workers, ${ }^{79}$ persons with disabilities, ${ }^{80}$ the LGBT community, ${ }^{81}$ and young women who have been the victims of human trafficking. ${ }^{82}$

Although many of the Chiangmai-based activists are Americans and Europeans, a number of them are Thai, and the programs in which they work are home grown. Moreover, many Thai faculty members at Chiang Mai University ${ }^{83}$ (CMU) labor tirelessly in rural and urban settings to promote the cause of human rights, often at great personal risk and expense. For example, Virada Somswasdi, the founder of the Women's

76. Id. at 178 .

77. Sally Engle Merry, Transnational Human Rights and Local Activism: Mapping the Middle, 108 AM. ANTHROPOLOGIST 38, 49 (2006).

78. See, e.g., ASIA PACIFIC FORUM ON WOMEN, LAW AND DEVELOPMENT, http://www.apwld.org (last visited Apr. 15, 2012).

79. See, e.g., MAP FOUNDATION, http://www.mapfoundationcm.org/eng (last visited Apr. 15, 2012).

80. See, e.g., Foundation to Encourage the Potential of Disabled Persons, http://www.disabled.infothai.com (last visited Apr. 15, 2012).

81. See, e.g., MPLUS FOUNDATION, http://www.mplusthailand.com (last visited Apr. 15, 2012).

82. See, e.g., ANTI-TRAFFICKING COORDINATION UNIT NORTHERN THAILAND (TRAFCORD), http://trafcord.org/content/about-trafcord (last visited Apr. 15, 2012).

83. Chiang Mai is an alternate English transliteration of Chiangmai. 
Studies Center at CMU, trains paralegals from village settings throughout northern Thailand, where they return and work in their own communities to promote women's rights in particular and human rights in general. 84

In an article about legal consciousness in Thailand, Frank Munger discusses one example in which political activists drew on rights-based concepts to mobilize grass roots opposition to construction and management of the Pak Mun Dam in Thailand's northeast region. ${ }^{85}$ Villagers whose homes and livelihoods were affected by the dam collaborated with NGO activists to organize a series of protests from the 1990 s to the present, citing not only the international human rights issues at stake but also what Munger describes as deep-rooted cultural values related to environmental protection. ${ }^{86} \mathrm{He}$ suggests that environmental protests of this kind, drawing on international rights. based discourses, affected the drafting of the 1997 Constitution, which "provides special protections for environmental rights and for public participation in environmental decision-making." 87 Thus, in Merry's terms, the Pak Mun Dam protests illustrate one area in which transnational rights were successfully translated into a set of concepts that were meaningful to villagers and which they in turn could mobilize to affect the framework of state law. Significantly, Munger concludes that "social justice among the rural poor was grounded in the unique importance of the environment rather than a general belief in rights or democracy." 88

The Pak Mun Dam controversy, and others like it, provide valuable case studies in the vertical tradition, demonstrating how actors at the grass roots level translate and deploy rights concepts formulated at the international level to provide leverage for effective political action. What the vertical perspective is not designed to tell us in such cases, however, is the horizontal breadth of this form of legal consciousness. To what extent have villagers generally in northeast Thailand, or persons throughout Thai society, actually translated or otherwise integrated rights concepts into their sense of self, their understandings of society, or their perceptions of environmental and other issues? A different methodology would be required to answer this somewhat different question, and researchers would need to conduct interviews and

84. See Paralegal Training, WOMEN's STUDIES CENTER, http://wsc.soc.cmu.ac.th/ paralegal.htm (last visited Apr. 15, 2012).

85. Frank Munger, Culture, Power, and Law: Thinking About the Anthropology of Rights in an Era of Globalization, 51 N.Y.L. SCH. L. REV. 817, 836 (2007).

86. Id. at 835 .

87. Id. at 837 .

88. Id. at 838 . 
observations not only with individuals who participated in these organized protests but also with those who did not.

I am certain that a researcher employing the vertical model could find many other examples in Chiangmai and throughout Thailand of the processes of dissemination and vernacularization that Merry has traced in India, China, Fiji, Hawai'i and elsewhere. ${ }^{89}$ Additionally, a researcher could show how concepts and practices originating in elite international conferences and organizations have filtered down to ground level in Thailand. This vertical perspective on transnational legalism has great value and is valid and accurate in its own way. But there is one thing it cannot tell us. Research on the dramatic proliferation of these activities in Thailand cannot tell us, in Merry's words, whether they "achieve an expanded human rights subjectivity" among significant numbers of people in various types of social settings, across other fields of social interaction, or within broader social classes or strata..$^{90}$

Why is this a problem? Why is it important to specify so carefully the limitations of vertical methodologies when they do not incorporate horizontal elements to investigate forms of consciousness that may feature a variety of discourses other than or in addition to liberal legalism? Without this kind of methodological self-scrutiny, there is a heightened risk of getting things wrong. We tend to believe-and most of us want to believe-that rights consciousness is continually expanding. But the Thai example suggests that, despite superficial indications to the contrary and despite increased activity by some rights advocates, rights consciousness may actually be contracting as a direct result of globalization. If our research does not extend outside the boundaries of the conceptual system we are studying, then we will have little sense of whether and in what social settings that system is growing or shrinking relative to rival conceptual systems. We may be surprised, for example, by the unexpected realization that a broad-based religious resurgence has far more appeal to ordinary people in some social settings-such as the Thai urban middle class-than does the ideology of rights. ${ }^{91}$

We have made this kind of mistake before, but socio-legal scholars seem particularly well qualified to guard against such misreadings-as long as we maintain our historic commitment to distinguishing between the normative dimensions of law and its empirical manifestations. The

89. MERRY, supra note 67 , at 31-35.

90. Id. at 49 .

91. See Apinya Fuengfusakul, Empire of Crystal and Utopian Commune: Two Types of Contemporary Theravada Reform in Thailand, $8 \mathrm{~J}$. SOC. ISSUES IN SOUTHEAST ASIA 153 (1993) (discussing contemporary Thai religious movements among the urban middle class). 
need is apparent in Thailand, where observers tend to assume that constitutional rights are meaningful to ordinary people and that there is a growing tendency not only among the urban middle class but even among the predominantly rural population to invoke rights discourse and make use of the new institutions for securing those rights. But it would be better to present these assertions as research questions rather than conclusions. As Anna Tsing has observed, "[i]n globalization theories, we have confused what should be questions about the global ramifications of new technologies and social processes with answers about global change."92 It would be a serious mistake to read social behavior through the lens that is most familiar to, and preferred by, the observer rather than asking what ideas, values, and conceptual frameworks are meaningful to the actors themselves. The result could be a fundamental misinterpretation of the current situation facing Thai society, as well as a strong likelihood of error in our predictions for the future.

\section{RIGHTS CONSCIOUSNESS AND IDENTITY}

Law and society research for many years has challenged the assumption that the norms and procedures of official law translate themselves unproblematically into the everyday practices of ordinary people. The relationship between formal rights and legal consciousness is always complex and seldom predictable. Countless studies of legal rights and the law in action have, however, yielded some fundamental insights. Law and society research has consistently demonstrated that legal rights are very often either unfamiliar to or are deliberately rejected by their intended beneficiaries; that other value systems or normative arrangements tend to be prized more highly than the law; that potential claimants often view the pursuit of legal rights and remedies as destructive of important relationships; and that lumping is the default mode of conflict resolution. 93

How relevant are these axiomatic findings to law and society research on rights consciousness in the global era? I suggested earlier in

92. Anna Tsing, Conclusion: The Global Situation, in THE ANTHROPOLOGY of GLOBALIZATION: A READER 453, 476 (Jonathan Xavier Inda \& Renato Rosaldo eds., 2002).

93. A vast research literature documents the widespread tendency to subordinate rights claims to relational considerations or to other systems of norms and values. See, e.g., Bryant G. Garth \& Austin Sarat, Studying How Law Matters: An Introduction, in How Does LaW MaTTER? 1 (Bryant G. Garth \& Austin Sarat, eds., 1998); Marc Galanter, Why the "Haves" Come Out Ahead: Speculations on the Limits of Legal Change, 9 LAW \& Soc'Y REV. 95 (1974); Stuart Macaulay, Law and the Behavioral Sciences: Is There Any There There?, 6 L. \& POL'Y 149 (1984). 
this Article that rights consciousness emerges from the intersection of individual identity construction and the discourses available in the social environment for dealing with experience and conflict. ${ }^{94}$ Tracking the transformations of rights consciousness over an individual's life experience may allow researchers to incorporate both vertical and horizontal elements and thereby avoid exaggerated conclusions about the role rights actually play for ordinary people. This section provides an illustration of the use of life story narratives in research on rights consciousness. It traces the story of Buajan, an accident victim in Chiangmai, during a critical ten-year span in her life. Buajan's story reveals how rights discourse and knowledge of formal legal institutions can be modified by religious and other world views, which ultimately prevailed over law in her thoughts and actions.

Buajan, a middle-aged woman from a rural background, moved to the city of Chiangmai some years ago. After her arrival, she engaged in a series of low-wage jobs, most recently as a cook in the restaurant of a local hotel. When we spoke with her in 1999 , she was still recovering from painful surgery for a serious injury to her leg. The injury occurred while she was standing next to a pork stand near the side of a road. There, a car driven carelessly by an elderly man ran her over, then backed up and struck her again. As she told the story in 1999, the old man, whom she called "Uncle," acknowledged his responsibility for the injury and offered a payment of 20,000 baht along with a promise to "clear" all her expenses. When the hospital released her, however, Uncle rejected any further reimbursement of Buajan's costs, arguing that everything had been included in his initial payment. Buajan tried to file a complaint with the police, but they turned her away on the grounds that the parties had already reached a private settlement.

During our first interview, Buajan's description of the injury revealed the multiplicity of causal explanations available in her social environment, as well as her sense of self, her remembered past, and her aspirations for the future. As we have described elsewhere, ${ }^{95}$ she framed her injury in multiple ways, shifting from one perspective to another with no difficulty or sense of inconsistency. The diversity of interpretive frames reflected the broad array of conceptual systems-including but not limited to rights discourse-that were available horizontally to Buajan. She initially asserted that a ghost in a nearby tree caused her injury, but at another point she blamed an ancestral spirit that had been offended by the sexual impropriety of a young relative. At yet another moment in our conversation, she said that the injury was

94. See supra note 8.

95. ENGEL \& ENGEL, supra note 38 , at 21-32. 
caused by her own bad karma resulting from misdeeds in this life and in past lives. At still another point, she cited the negligence of Uncle, and of herself.

Buajan's belief in supernatural causes derived from the Lanna spirit practices of her childhood, which she described as an important part of her identity. But after she moved from her rural home, she found herself separated from her birth community and from the spirits and authority figures who could enforce customary norms against her resistant injurer. In the place of village-based spirit practices, the more abstract norms of Buddhism had expanded and come to predominate in her spiritual life. Buddhism was central to her sense of self, and it was primarily through the lens of Buddhism that she accounted for the injury she received. For example, she told us that she had once struck a dog and broken its leg; but now the karmic consequences of her bad deed had caught up with her and her own leg was broken. Moreover, she may have injured "Uncle" in a past life, creating bad karma that resulted in his injuring her in their present incarnation.

A purely Buddhist perception of her injury might have led Buajan to blame herself for the injury and seek a solution in the form of meritmaking to ward off future harm. Moreover, by refraining from the aggressive pursuit of a remedy, she could demonstrate the Buddhist virtues of compassion, mercy, and nonattachment, thus adding to her store of merit and protecting against future harm to herself and her family.

Buajan, however, viewed her injury through yet another lens. She also saw herself in legal terms as the innocent victim of a negligent driver who was too old and sick to have been behind the wheel in the first place. In this interpretive frame, she was a woman whose rights had been violated, although she never spoke of rights herself. Offering one of the only references to law in all of our interviews, she told us that she had informed Uncle during their negotiations that she could file a lawsuit if she were so inclined. Yet, she admitted, she did not trust the law enough to pursue her sense of a legal violation. She told us that poor people like herself could never use the law to obtain a remedy against wealthy and influential people like Uncle: "I never filed a legal complaint. Even if I had, he could have turned it all around and made me out to be the one in the wrong." In 1999, Buajan was angry and frustrated. She felt she had been treated unjustly, but in the end she relied on her belief that the law of karma rather than the law of torts or the criminal law was the most effective way to hold her injurer accountable.

Ten years later, when we spoke again with Buajan, her sense of identity had clearly changed with the passage of time and so had the 
story she told about her injury. Much had happened to her during the intervening years. Her physical recovery had been slow and painful, and she had been forced to leave her job. One of her children had died, her husband had become seriously ill and incapacitated, and Buajan herself had undergone surgery for a growth on her uterus. She was forced to work as a janitor, but that had proved beyond her physical capacity, and by the time we spoke she was supporting her family by selling food from a mobile cart in the evenings. She had become even more devout and read religious texts studiously. One evening, while reading a book about Jao Mae Kuan Im, the popular Goddess of Mercy, she fell asleep and had a dream:

I saw an old man. In the dream, I was lost and couldn't find my way home. I was hungry and begged him for some rice. He reached into his shoulder bag, this bald guy in my dream, and gave me some very black rice to eat. It caught in my throat, and I began to choke. That's when I woke up.

Buajan interpreted the dream as a sign that she had behaved improperly toward Uncle in her dispute with him over compensation. She had spoken to him in anger and had been too aggressive-one might say too law-oriented-in seeking payment for her costs and her lost wages. From the perspective of the Buddhist teachings that had increasingly guided her life, she now realized that all the misfortune she had suffered in the aftermath of her accident had resulted from her failure to respond to her injury in accordance with thamma [dharma] ${ }^{96}$

Armed with this realization, Buajan made a remarkable decision. She got on her motorcycle and rode to Uncle's house, two years after he had run her over. Buajan planned to beg for his forgiveness. She wanted to perform a blessing with lustral waters, the dam hua ceremony, and express regret for her actions. She described her intentions by stating, "I would have told him, Uncle, I truly apologize for speaking abusively to you. I used very strong language." This dramatic meeting, however, in which the innocent victim would have apologized to the negligent injurer for asserting her legal interests too aggressively, was not to take place. Uncle's younger relatives intercepted Buajan at the door and

96. The dictionary definition of thamma (or tham) is "Buddhist teaching, righteousness, dharma." MARY R. HAAS, THAI-ENGLISH STUDENT's DICTIONARY 253 (1964). Thamma or dharma is a fundamental concept in traditional Hindu-Buddhist thought. It refers to the teachings of the Buddha and also "signifies the eternal laws which maintain the world." ROBERT LINGAT, THE CLASSICAL LAW OF INDIA 3 (1973). 
refused to bring her to see Uncle, fearing that she had come to demand more money.

Nevertheless, Buajan's effort to resolve the conflict by a ritual display of her piety provides a vivid example of her reinterpretation over time of her sense of self and of the meaning of events that had occurred in her life. Instead of characterizing Uncle as a haughty and stingy member of the social elite, she now perceived him in different terms: "He was really like an older relative. If he hadn't said anything bad about me, I would have respected him. I would have loved him like a father. I miss having that kind of relationship with anyone." As Buajan reflected on her relationship with Uncle:

I just came to understand the accident . . . Looking back on it now, I think it was karma .... I think that in a previous life I must have done something to him and it was coming back to me. I didn't want us to have this connection in future lives. That was my belief. So I made merit for him.

In retelling the story of her accident ten years later, Buajan also referred to facts she had omitted in her original narrative. She now acknowledged that, shortly after the accident, Uncle not only offered a payment of 20,000 baht but also knelt and bowed his head to her feet, saying, "Child, you don't have to report this to the police. I'll take care of everything." For an elder to bow down in this way to a woman of "inferior" age and social status was highly unusual. Yet his gesture did not dissuade Buajan from attempting to file a police report after he failed to fulfill his promises, and in Buajan's view, tried to intimidate her by referring to his connections in high places.

In short, Buajan's narrative and its transformation over a ten-year period illustrates the fluidity of rights consciousness and its tendency to change over time as individuals interpret their experiences within the discursive frameworks they find available in their social environments. For Buajan, the thought of legal recourse surfaced briefly during her initial interaction with Uncle, but it was submerged by other discourses and interpretive frames, leaving only a residue of dissatisfaction and frustration. Ten years later, even the brief insistence on her legal interests now appears to Buajan to have been a disastrous mistake. Viewed entirely through the lens of Buddhist teachings, her initial pursuit of a remedy now appears to have precipitated even more suffering, illness, and death. She longs for the opportunity to make amends, to perform a sacred ritual for the old man, and to change their relationship from one of self-interested adversarialism to one of love. 
Buajan's story exemplifies how identity and individual experience can link up with particular discourses to reshape rights consciousness. In this example, rights consciousness includes the possibility of rejecting, as well as embracing, rights. Buajan's initial, hesitant reference to the law was followed in our conversation ten years later by a more emphatic rejection, which resulted from an increased commitment to Buddhism in relation to alternative discourses-as well as a series of tragic misfortunes in Buajan's life. The emergence of this distinctive form of rights consciousness has no place in the usual accounts of a global expansion of liberal legalism. Even in the Thai context, it is difficult to reconcile the evolution of Buajan's rights consciousness with the widespread reporting of increased litigiousness, rights-based political movements, the activities of NGOs, and the central role of constitutional rights in modern Thai society.

Buajan's story illustrates how a horizontal perspective can supplement the predominantly vertical view of rights consciousness in Thailand and elsewhere. By listening to narratives such as hers, and by watching them evolve and transform themselves over time, it is possible to step outside the confines of an exclusively vertical perspective, while still acknowledging its heuristic potential. Instead of tracing only the increased flow of rights concepts from one level to another, such combined approaches consider the full range of concepts that are evident in the narratives of ordinary people. These approaches can identify rights-based concepts when and if they emerge, but they can also place them in relation to other frameworks that may prove far more important to ordinary people. In this way, the actual reach of rights, and their tendency to expand or contract in relation to other discourses, can be meaningfully assessed.

\section{CONCLUSION}

The poster on the schoolhouse wall in the small village outside Chiangmai City represented a nexus point for the vertical and horizontal perspectives on rights consciousness. From a vertical perspective, the poster illustrated the processes of translation and adaptation through which rights concepts originating in distant but prestigious international organizations became familiar images and words transmitted by the national government to the grassroots level. From a horizontal perspective, however, the poster illustrated something quite different-the futility of relying on rights to change the thoughts and actions of the villagers, who probably paid the poster little heed. Interviews conducted that day by my students revealed that the villagers tended to share Buajan's disregard for the rights concepts 
articulated by the poster, and for reasons similar to hers. Indeed, many local residents had, like Buajan, already emigrated from this village to live and work elsewhere. In their new homes, far from their birth community, they would have found that customary village norms no longer had much relevance or utility in their lives, yet my research suggests that they would not have viewed liberal legalism as an attractive substitute. Thus, the perspective on rights consciousness afforded by Buajan's story, and by interviews pursued horizontally across a community or other social field, may underscore the disconnection between the lofty ideals expressed in the poster and the actual views and practices of ordinary people.

For those who might adhere only to the vertical perspective, a different conclusion could easily have been drawn. The poster could have been viewed in connection with numerous other constitutional, statutory, and institutional advances as well as the activities of a growing number of individuals and organizations that advocate the cause of rights in Thailand. The poster, from that perspective, could be interpreted as yet another advance for liberal legalism, a cause that most of us would probably desire for the citizens of Thailand.

In this Article, I have not argued that such a trend would be unwelcome-quite the reverse, I see many ways in which the advance of rights could help to resolve some of Thailand's most pressing problems. Rather, I have urged the importance of distinguishing carefully between a normative preference for rights and a grounded effort to answer the empirical question of whether rights play a meaningful role in the consciousness of ordinary people. To answer this question, I have suggested researchers cannot remain inside what Yngvesson calls the "imaginary of neoliberal culture" 97 but must also step outside and take an external-horizontal-view of the entire range of conceptual frameworks available to people in particular social settings. Researchers must watch and listen as individuals navigate among these frameworks over time as circumstances change. Only by combining horizontal and vertical approaches can researchers place the project of liberal legalism in its broader social context and gain some understanding of its successes and failures. In the process, we may discover that other projects are also underway, some of them quite powerful and capable of weakening or subverting the cause of rights entirely.

97. Yngvesson, supra note 6. 